\title{
Pengetahuan Mengenai Insulin dan Keterampilan Pasien dalam Terapi
}

\author{
Komala Appalanaidu \\ Program Studi Pendidikan Dokter, Fakultas Kedokteran Universitas Udayana \\ (rianot alone@yahoo.com)
}

\begin{abstract}
ABSTRAK
Diterima: 15 Maret 2016. Disetujui: 6 April 2016. Diterbitkan: Juni 2016

Insulin adalah hormon peptida, yang diproduksi oleh sel beta pankreas, dan merupakan pusat metabolisme karbohidrat dan lemak dalam tubuh kita. Sebagian besar pasien diabetes bisa mengontrol kadar glukosa mereka selama bertahun-tahun dengan diet yang baik dan latihan rutin ditambah satu, dua atau bahkan tiga jenis obat. Namun, ada banyak obat ini tidak efektif atau tidak lagi aman bagi pasien, misalnya resiko penyakit ginjal dan penyakit hati.

Pasien dengan komplikasi Diabetes seperti ketoasidosis atau hiperglikemia parah (gula darah > 500 $\mathrm{mg} / \mathrm{dL}$ ) merupakan indikasi untuk terapi insulin. Pasien dengan adanya infeksi serius seperti pneumonia dan pasien dengan penyakit bersamaan seperti serangan jantung harus mulai terapi insulin segera. Selain itu, pasien selama atau setelah operasi dan selama kehamilan harus mulai terapi insulin. Jika beban glikemik yang ideal yang gagal dicapai dengan dua atau tiga obat oral, pasien harus mulai terapi insulin. Tingkat A1C lebih dari $10 \%$ atau $7,5 \%$ dengan glukosa darah puasa lebih dari $250 \mathrm{mg} / \mathrm{dL}$ juga merupakan indikasi untuk menggunakan insulin.

Sebagai akibatnya, insulin digunakan secara medis untuk mengobati beberapa bentuk diabetes mellitus. Pasien dengan diabetes tipe 1 bergantung pada insulin eksternal (paling sering disuntikkan subkutan) untuk kelangsungan hidup mereka karena hormon yang tidak lagi diproduksi secara internal. Pasien dengan diabetes tipe 2 sering resisten insulin dan, karena perlawanan tersebut, mungkin menderita kekurangan insulin "relatif". Beberapa pasien dengan diabetes tipe 2 mungkin akhirnya membutuhkan insulin jika obat lain gagal untuk mengontrol kadar glukosa darah secara memadai.

Ada hubungan antara pengetahuan pada insulin dan keterampilan pasien dalam terapi insulin. Hal ini penting bagi pasien untuk mengetahui lebih banyak tentang penyakit mereka dan pengobatan untuk menghindari komplikasi dan juga risiko penyakit.
\end{abstract}

Kata kunci : Insulin, Terapi

\section{PENDAHULUAN}

Insulin menyebabkan sel-sel di hati, otot rangka, dan jaringan lemak untuk menyerap glukosa dari darah. Insulin adalah hormon peptida, yang diproduksi oleh sel beta pankreas, dan merupakan pusat mengatur metabolisme karbohidrat dan lemak dalam tubuh kita. Dalam hati dan otot rangka, glukosa disimpan sebagai glikogen, dan di adiposit itu disimpan sebagai trigliserida. Insulin menghentikan penggunaan lemak sebagai sumber energi dengan menghambat pelepasan glukagon. Dengan pengecualian dari diabetes mellitus gangguan metabolisme dan sindrom metabolik, insulin diberikan dalam tubuh dalam proporsi konstan untuk menghilangkan kelebihan glukosa dari darah. Ketika kontrol kadar insulin gagal, diabetes mellitus dapat menyebabkan. Sebagai akibatnya, insulin digunakan secara medis untuk mengobati beberapa bentuk diabetes mellitus. Pasien dengan diabetes tipe 1 bergantung pada insulin eksternal (paling sering disuntikkan subkutan) untuk kelangsungan hidup mereka karena hormon yang tidak lagi diproduksi secara internal. 
Pasien dengan diabetes tipe 2 sering resisten insulin dan, karena perlawanan tersebut, mungkin menderita kekurangan insulin "relatif". Beberapa pasien dengan diabetes tipe 2 mungkin akhirnya membutuhkan insulin jika obat lain gagal untuk mengontrol kadar glukosa darah secara memadai.

Pasien yang berkeliling di bawah terapi insulin harus tahu apakah jenis jenis insulin yang ada dan juga tipe insulin yang lebih baik buat diri sendiri . Tidak seperti pasien di bawah terapi insulin yang tidak bepergian, mereka yang bepergian sering pergi ke tempat-tempat lebih jauh dari dokter yang melakukan pemeriksaan rutin mereka. Mereka mungkin juga melakukan perjalanan sendiri ke beberapa tempat tanpa orang untuk menemani mereka. Pasien juga harus memiliki situasi di mana mereka harus membeli insulin di tempat mereka pergi dan informasi tentang jenis insulin dan dosis yang harus diambil selalu sangat penting. Selain itu, pasien yang bepergian biasanya cenderung untuk mencoba makanan yang berbeda dan makan yang jauh lebih berbeda dari biasanya. Hal ini mungkin menyebabkan peningkatan risiko kontrol kadar gula darah yang miskin. Mereka berada dalam risiko tinggi untuk hal yang salah jika mereka tidak mengisi diri dengan informasi dasar cukup tentang insulin.

Pasien di bawah terapi insulin harus tahu apa itu insulin termasuk mekanismenya, keselamatan dan pencegahan selama terapi insulin dan sebagainya . Pasien juga harus tahu bagaimana cara menggunakan insulin dengan cara yang tepat sehingga akan ada lebih sedikit efek samping dan masalah lainnya mengenai terapi insulin. Dalam terapi insulin sangat penting untuk menempati pasien pada dosis insulin penyesuaian sesuai dengan asupan makanan mereka sepanjang perjalanan mereka. Selain itu, pasien juga dapat mengajukan pertanyaan mengenai insulin dan menghapus keraguan bahwa mereka tidak mungkin telah meminta dokter yang mereka selalu berkonsultasi .

Pasien lebih sadar tentang terapi insulin termasuk mekanisme aksi dan efek samping yang mungkin terjadi selama penggunaannya . Kami juga mampu mengenali masalah umum yang pasien hadapi selama terapi insulin dan kita akan dapat meningkatkan pelayanan kami di masa depan sebagai dokter yang menangani pasien dengan kasus yang sama.

\section{METODOLOGI PENELITIAN}

\section{Tempat Dan Waktu}

Studi dilakukan di Pusat Diabetes RSUP Sanglah pada periode dari 29 Januari 2013 sampai 6 Februari 2013.

\section{Desain Penelitian}

Penelitian ini dilakukan dengan menggunakan seperangkat kuesioner disertai dengan sesi wawancara singkat dengan pasien yang berkunjung ke poliklinik untuk kontrol rutin . Setelah wawancara, rekam medis dirujuk untuk mengisi catatan medis mereka saat ini . Data yang diambil meliputi nama lengkap pasien, usia, jenis kelamin , kadar glukosa darah ( puasa dan pasca prandial ), tingkat $\mathrm{HbA1c}$, kolesterol , trigliserida , HDL dan LDL .

\section{Sampel dan Populasi}

Populasi sasaran buat studi ini adalah pasien rawat jalan dengan riwayat penyakit diabetes yang menerima terapi insulin. Sampel populasi untuk studi ini adalah pasien rawat jalan dengan riwayat penyakit diabetes dengan terapi insulin yang datang ke Pusat Diabetes RSUP Sanglah untuk pemeriksaan rutin .

\section{PENGUMPULAN DATA}

\section{Pemilihan Subyek Penelitian}

Subjek penelitian untuk studi ini adalah pasien rawat jalan dengan Diabetes Mellitus yang datang ke Pusat Diabetes RSUP Sanglah untuk pemeriksaan rutin dan juga memenuhi kriteria inklusif dan eksklusif.

\section{Metode Pengumpulan Data}

Data untuk studi ini dikumpul dari catatan medis pasien. Anamnesis dilakukan terhadap pasien untuk mengisi kuesioner

\section{Variabel Penelitian}

Variabel yang digunakan dalam penelitian ini adalah sebagai berikut :

1. Variabel dependen : Keterampilan dalam menggunakan insulin 
2. Variabel bebas: Tingkat pengetahuan tentang insulin

3. Variabel perancu : Umur pasien, berapa lama telah di terapi insulin

\section{Definisi Variabel Operasional}

Pasien yang menjalani terapi insulin adalah pasien yang menggunakan insulin dan datang untuk pemeriksaan rutin di Pusat Diabetes RSUP Sanglah. Data disediakan berasal dari rekam medis pasien yang disimpan di Pusat Diabetes RSUP Sanglah .

\section{HASIL}

\section{Karakteristik Subyek Penelitian}

Dalam penelitian ini, terdapat jumlah 10 sampel yang memenuhi kriteria inklusif dan eksklusif . Sampel terdiri dari 2 perempuan dan laki-laki 8 . Usia sampel berkisar berusia 54-63 tahun. Semua sampel memiliki berbagai tingkat glukosa dan durasi terapi insulin.

\section{ANALISIS HASIL}

\section{Anamnesis}

Berdasarkan anamnesis , $30 \%$ dari sampel menderita Diabetes Mellitus kurang dari 6 tahun . $10 \%$ dari sampel menderita Diabetes Mellitus 6 sampai 10 tahun dan $60 \%$ dari mereka lebih dari 10 tahun. Hal ini menunjukkan bahwa, mayoritas pasien dari sampel yang menderita Diabetes Mellitus adalah lebih dari 10 tahun .

Kami menemukan bahwa, semua pasien makan normal yaitu tiga kali sehari dan jumlah makanan ringan yang diambil bervariasi . $70 \%$ dari pasien yang diwawancarai makan makanan ringan dalam jumlah yang sangat rendah . $20 \%$ dari pasien yang diwawancarai makan makanan ringan dalam jumlah sedang dan hanya $10 \%$ makan dalam jumlah besar.

$60 \%$ pasien yang diwawancarai tidak aktif secara fisik. Sisa $20 \%$ dan $10 \%$ dilaporkan untuk tingkat aktivitas fisik yang sedang dan tinggi . $50 \%$ dari pasien yang diwawancarai tidak melakukan olahraga apapun. $20 \%$ dari pasien berolahraga kurang dari 30 menit dan sisanya $30 \%$ tidak berolahraga lebih dari 30 menit .

$70 \%$ dari pasien menggunakan obat anti - diabetes yang diresepkan oleh dokter. $10 \%$ dari mereka menggunakan kedua obat anti - diabetes yang diresepkan oleh dokter dengan obat alternatif atau tradisional . $10 \%$ pasien hanya menggunakan alternatif atau obat-obatan tradisional .

$30 \%$ pasien memiliki disiplin yang sangat buruk dalam mengikuti pengobatan . 30\% dari mereka kadang-kadang lupa untuk mengambil obat mereka. Sisanya $40 \%$ memiliki disiplin yang sangat baik dalam mengikuti pengobatan. Mereka tidak pernah lupa untuk mengambil obat mereka . Di antara pasien yang kami wawancarai , hanya 20 $\%$ memiliki komplikasi diabetes. Diabetes Neuropati dan diabetes Ketoasidosis adalah komplikasi yang kami temukan. Sisanya $80 \%$ dari pasien pernah mengalami komplikasi.

$10 \%$ dari sampel tidak memiliki pengetahuan apaapa tentang kondisi mereka dan ketika ditanya mereka mengatakan mereka tidak tahu apa itu Diabetes Mellitus . $70 \%$ dari pasien tahu sedikit tentang Diabetes Mellitus dan hanya $20 \%$ dari pasien yang diwawancarai tahu apa yang Diabetes Mellitus . Kita dapat menyimpulkan bahwa, sebagian besar pasien tidak tahu tentang Diabetes Mellitus di Bali .

$80 \%$ dari pasien yang diwawancarai mengatakan bahwa mereka tidak memiliki riwayat keluarga diabetes mellitus. Tak satu pun dari anggota keluarga mereka menderita Diabetes Mellitus . Hanya $20 \%$ dari pasien mengatakan bahwa mereka memiliki keluarga dengan Diabetes Mellitus. Hal ini menunjukkan bahwa pasien dengan Diabetes Mellitus memiliki faktor genetik sangat kurang predisposisi .

\section{Riwayat Pemakaian Insulin}

$10 \%$ dari pasien telah menggunakan insulin untuk kurang dari satu tahun . $40 \%$ dari mereka telah menggunakan insulin dari 1 sampai 3 tahun . $50 \%$ dari pasien yang menggunakan insulin selama lebih dari 3 tahun. Dosis yang diambil adalah $50 \%$ kurang dari 40 unit dan $50 \%$ lebih dari 40 unit . $50 \%$ dari pasien yang menggunakan insulin basal saja. $20 \%$ dari mereka menggunakan insulin prandial saja. $30 \%$ dari pasien yang menggunakan kedua basal dan prandial juga insulin.Almost semua pasien mengubah situs injeksi insulin secara teratur. Tempat yang paling umum adalah lengan , perut dan paha. Dan $90 \%$ dari pasien tidak membutuhkan bantuan dalam menyuntikkan insulin . 
$40 \%$ dari pasien tidak memiliki efek samping setelah menggunakan insulin. Sisa $60 \%$ dari pasien memiliki efek samping. Efek samping yang paling umum dikeluhkan oleh pasien adalah berat badan, hipoglikemia, dan arthritis .

Selain efek samping yang dibawa oleh insulin, ada juga beberapa titik ditambah terapi ini . $50 \%$ dari pasien berpikir bahwa terapi insulin telah membantu mereka begitu banyak dalam mengatur kadar glukosa mereka secara efektif . 40 \% dari pasien berpikir bahwa terapi insulin tidak banyak berpengaruh pada mempertahankan tingkat glukosa mereka.

\section{Kondisi Psikologis Pasien}

Sebanyak $70 \%$ pasien yang diwawancarai merasa sangat kecewa dan sedih setelah mereka didiagnosis dengan Diabetes Mellitus . Sisanya 30 $\%$ dari mereka tidak merasa apa-apa setelah diagnosis telah dikonfirmasi . $80 \%$ dari pasien tidak pernah merasa sebarang perubahan nafsu makan mereka. Mereka makan normal dan menunjukkan bahwa tidak ada episode depresi pada pasien ini. Sedangkan $20 \%$ sisanya dari mereka memiliki perubahan nafsu makan mereka. Mereka mengatakan bahwa mereka takut untuk makan dan juga nafsu makan mereka akan hilang begitu sahaja .

$90 \%$ dari pasien tidak pernah kehilangan minat dalam hobi mereka setelah mereka didiagnosis dengan Diabetes Mellitus. Aktivitas sehari-hari mereka telah normal. $10 \%$ dari pasien mengalami kurangnya minat dalam hobi mereka dan hal-hal yang mereka sukai. Hal ini menunjukkan bahwa mereka mengalami depresi ringan setelah Diabetes Mellitus telah didiagnosis . Tapi, tidak ada pasien yang diwawancarai kehilangan harapan mereka dalam bertahan hidup dan tidak ada usaha bunuh diri yang dilakukan oleh pasien yand diwawancarai .

Sebagian besar pasien yang diwawancarai mengatakan bahwa mereka mendapatkan dukungan dari keluarga mereka. Keluarga mereka telah selalu ada untuk mendukung mereka dalam setiap keadaan. Dan ketika ditanya, mereka juga percaya bahwa mereka dapat hidup bahagia dengan mereka walaupun dengan terdiagnosa Diabetes Mellitus dengan gaya hidup sehat dan mereka tidak pernah kehilangan harapan.

\section{DISKUSI}

\section{Pengetahuan Tentang Insulin dan Keterampilan dalam Terapi Insulin}

Pengetahuan tentang insulin jelas mempengaruhi keterampilan dalam terapi insulin. Pasien yang tahu lebih banyak tentang insulin memiliki keterampilan tinggi dalam terapi insulin . Misalnya, insulin digunakan untuk memantau kadar glukosa. Para pasien yang sangat baik memahami konsep ini akan dapat menyesuaikan dosis insulin sesuai dengan asupan makanan mereka sehingga kadar glukosa mereka akan dipantau dengan sempurna dan kurang kemungkinan mendapatkan hipoglikemia .

Selain dosis, pasien dengan lebih pengetahuan tentang insulin akan dapat menyuntikkan insulin di tempat yang tepat sehingga risiko injeksi intramuskular dapat dicegah. Untuk mengurangi risiko ini , pasien harus menyadari teknik mencubit kulit. Kulit harus dicubit untuk mengurangi resiko infeksi pada area injeksi akibat injeksi berulang . Teknik mencubit hanya digunakan pada pasien yang kurus tidak usah dicubit bagi pasien yang gemuk. Penyerapan insulin adalah pengetahuan yang sangat dasar dimana pasien yang menggunakan insulin harus tahu .

\section{Faktor Pembatas}

Penelitian ini didasarkan pada kuesioner dan anamnesis. Ada beberapa faktor yang membatasi selama penelitian dilakukan :

1. Tidak ada cukup waktu untuk melakukan penelitian.

2. Jumlah sampel yang dikumpul sedikit. Pada penelitian seterusnya, sampel harus dikumpulkan di ruangan sehingga akan ada lebih banyak pasien yang menggunakan insulin .

3. Kerjasama kurang dari pasien dengan kami.

\section{SIMPULAN}

Ada hubungan antara pengetahuan pada insulin dan keterampilan pasien dalam terapi insulin . Hal ini penting bagi pasien untuk mengetahui lebih banyak tentang penyakit mereka dan pengobatan untuk menghindari komplikasi dan juga risiko penyakit.

SARAN 
Lebih banyak studi perlu dilakukan secara mendalam dengan skala yang lebih besar dari populasi untuk mengetahui hubungan yang lebih jelas. Sampel juga dapat diambil langsung dari masyarakat daripada di rumah sakit . Lebih banyak waktu juga harus diberikan sehingga lebih banyak sampel dapat dikumpulkan dalam penelitian berikutnya.

\section{DAFTAR PUSTAKA}

1. Norbert Hermanns. (2010), "Barriers towards insulin therapy in type 2 diabetic patients: results of an observational longitudinal study", Health and Quality of Life Outcomes.

2. Linda Siminerio, PhD, RN, CDE. (2011), "Strategies for insulin injection therapy in diabetes self-management", American Association of Diabetes Education.

3. Marina Mahr. (2007), "Guide for Storage of Insulin".

4. Norman Chan. (2008), "Insulin therapy: Indication and Institution", CMPMedica.

5. Pradhan AD. (2012), "Diagnosis and Classification of Diabetes Mellitus", American Association of Diabetes Education, 35.

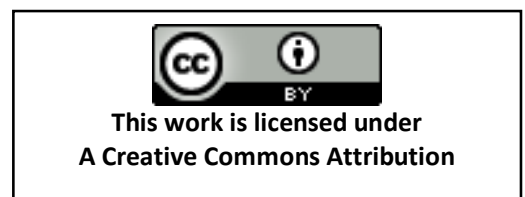

